\title{
DINAMIKA PEMBAHARUAN HUKUM KELUARGA ISLAM DI INDONESIA
}

\author{
Eko Setiawan \\ Universitas Bakti Indonesia Banyuwangi \\ oke.setia@gmail.com
}

\begin{abstract}
This article will elaborate the thought of renewing of Islamic family law in Indonesia. Family law generally is the law based on family ties. This family ties can occur because of consanguinity, or occur because of a marriage. The family relationships are very important because there is nothing to do with the relationship to the children and the parents, the law of inheritance, custody and guardianship. Basically source of family law can be divided into two kinds, namely the source of written and unwritten laws. Written source of family law is a source of law derived from a variety of legislation, jurisprudence, and treaties. While the source of the unwritten law is a source of law that grows and develops in society lifes.

Artikel ini akan menjelaskan tentang pemikiran pembaharuan hukum keluarga Islam di Indonesia. Hukum keluarga secara garis besar merupakan hukum yang bersumber pada pertalian kekeluargaan. Pertalian kekeluargaan ini dapat terjadi karena pertalian darah, ataupun terjadi karena adanya sebuah perkawinan. Hubungan keluarga sangat penting karena ada sangkut pautnya dengan hubungan anak dan orang tua, hukum waris, perwalian dan pengampuan. Pada dasarnya sumber hukum keluarga dapat dibedakan menjadi dua macam, yaitu sumber hukum tertulis dan tidak tertulis. Sumber hukum keluarga tertulis adalah sumber hukum yang berasal dari berbagai peraturan perundangundangan, yurisprudensi, dan traktat. Sedangkan sumber hukum tak tertulis adalah sumber hukum yang tumbuh dan berkembang dalam kehidupan masyarakat.
\end{abstract}

Kata Kunci: Pembaharuan, hukum keluarga, Islam

Hukum keluarga mempunyai posisi yang penting dalam Islam. Hukum keluarga dianggap sebagai inti syari'ah. Hal ini berkaitan dengan asumsi umat Islam yang memandang hukum keluarga sebagai pintu gerbang untuk masuk lebih jauh ke dalam agama Islam. Pada dasarnya sesuatu itu tidak akan terbentuk karena tidak adanya sesuatu hal yang mendasarinya, seperti halnya hukum keluarga Islam tidak akan pernah ada tanpa adanya sesuatu yang melatar belakanginya. Pembahasan ini penting dilakukan karena tidak semua masyarakat Indonesia beragama Islam sehingga sejarah, peristiwa dan sebab lahirnya hukum keluarga Islam dianggap sangat kontroversial.

Hukum keluarga Islam dirasa sangat penting kehadirannya di tengah-tengah masyarakat muslim karena permasalahan tentang keluarga menyangkut tentang perkawinan, kewarisan dan lain sebagainya yang tidak bisa disamakan dengan yang beragama non muslim, sehingga masyarakat menginginkan adanya hukum keluarga Islam yang berlaku khusus, apalagi dengan perkembangan zaman yang semakin berkembang pula sehingga dibutuhkan metodemetode untuk pembaruan hukum. Lahirnya Undang-Undang No. 1 Tahun 1974 tentang perkawinan dan KHI (Kompilasi Hukum Islam) adalah jawaban dari keresahan, ketidakpastian dan tuntutan masyarakat muslim untuk menjadi pedoman, dan rujukan dalam mengatasi permasalahan seputar hukum keluarga.

Pada zaman modern, khususnya abad ke20, bentuk-bentuk literatur hukum Islam telah bertambah menjadi dua macam, selain fatwa, keputusan pengadilan agama, dan kitab fiqh. 
Adapun yang pertama ialah undang-undang yang berlaku di negara-negara muslim khususnya mengenai hukum keluarga. Sedangkan yang kedua adalah kompilasi hukum Islam yang sebenarnya merupakan inovasi Indonesia. Kompilasi bukan kodifikasi, tetapi juga bukan kitab fiqh ${ }^{1 .}$

Sikap para ulama terhadap diundangkannya materi-materi hukum keluarga di negara-negara muslim telah menimbulkan pandangan pro dan kontra. Diantara para ulama ada yang tetap ingin mempertahankan ketentuan-ketentuan hukum lama dengan kalangan pembaharu baik yang menyangkut metodologi maupun substansi hukumnya. ${ }^{2}$ Sebagai contoh misalnya, dengan diberlakukannya UndangUndang No. 1 tahun 1974 tentang Perkawinan dan Undang-Undang No.7 tahun 1989 tentang Peradilan Agama, umat Islam Indonesia telah memiliki peraturan perundang-undangan yang memadai untuk mengatur masalah-masalah keluarga, perkawinan, perceraian dan warisan.

Sementara ulama tradisional Indonesia masih ada yang belum sepenuhnya memahami atau menyetujui berbagai aturan dalam kedua undang-undang tersebut karena dianggap tidak selamanya sesuai dengan apa yang termuat dalam kitab-kitab fiqh. Akan tetapi sebagian ulama lain merasa bangga dengan lahirnya kedua undang-undang itu karena dianggap sebagai kemajuan besar dalam perkembangan pemikiran hukum Islam di Indonesia. Apalagi dengan disepakatinya hasil Kompilasi Hukum Islam oleh para ulama Indonesia pada tahun 1988 yang kemudian diikuti oleh Instruksi Presiden No. 1 tanggal 10 Juni 1991 untuk menyebarluaskan dan sedapat mungkin menerapkan isi kompilasi tersebut, hal ini telah menandai lembaran baru dalam perkembangan pemikiran Islam di Indonesia khususnya dalam bidang hukum keluarga. ${ }^{3}$

Dari sini, penulis tertarik untuk mengkaji lebih dalam tentang dinamika pembaruan hukum keluarga Islam di Indonesia. Ada beberapa alasan yang mendorong penulis untuk

1 M. Mudzhar, "Dampak Gender Terhadap Perkembangan Hukum Islam”, Jurnal Studi Islam, 1, (1999), h. 172.

2 John Donohue, Islam dan Pembaharuan Ensiklopedi Masalah-Masalah. (Jakarta: Rajawali Press, 1995), h. 365

3 M. Mudzhar, Dampak.., h. 173 memilih judul tersebut, diantaranya adalah: (1) Dalam hukum keluarga di Indonesia perkawinan mendapatkan perhatian tersendiri. Secara substantif, hukum perkawinan Indonesia merupakan penjabaran hukum perkawinan dalam Islam. Sebagai negara dengan penduduk muslim terbesar di dunia, wajar jika bangsa Indonesia menjadikan Islam sebagai rujukan perundang-undangan, termasuk dalam perkawinan; (2) Di Indonesia dalam catatan sejarah, isu pembaruan hukum keluarga telah muncul sejak lama, sebelum kemerdekaan diraih. Pada momen Konggres Perempuan 1928, isu ini muncul karena banyaknya kasus yang menimpa kaum perempuan selama dalam kehidupan perkawinan. Seperti, terjadinya perkawinan di bawah umur, kawin paksa, poligami, talak yang sewenang-wenang dan mengabaikan hak-hak perempuan, dan sebagainya; (3) Hukum keluarga mempunyai posisi yang penting dalam Islam. Hukum keluarga dianggap sebagai inti syari'ah. Hal ini berkaitan dengan asumsi umat Islam yang memandang hukum keluarga sebagai pintu gerbang untuk masuk lebih jauh ke dalam agama Islam.

\section{Konsepsi Hukum Keluarga}

Hukum keluarga dalam pengertian perceraian, terdapat dalam berbagai kitab fiqhi di suatu negara. Pada umumnya kitab-kitab itu adalah hasil ijtihad pada mujâhid dari berbagai tingkatan untuk memenuhi kebutuhan hukum masyarakat muslim pada masanya. Hukum keluarga yang demikian dapat ditelusuri dalam kitab-kitab fikhi berbagai mazhab, seperti empat mazhab dalam sunni (Hanafi, Maliki, Syafi'i dan Hambali) dan tiga pada syiah (Itsna Asyari, Ismaili dan Zaidi).

Meskipun hasil penalaran para fuqaha di masa lampau telah memenuhi kebutuhan masyarakat muslim di masa itu, namun dalam konteks sekarang dianggap belum tentu sesuai. Disamping itu, isinya pun berbeda satu dengan lain karena tingkat penalarnya, meskipun mereka berada dalam satu mazhab yang sama. Adanya ketidakpuasan terhadap isi yang dikandungnya akibat perbedaan pendapat, menyebabkan masyarakat muslim yang belum paham justru mengikuti hukum adat yang turun temurun, bakan sistem hukum Kristen (barat) 
yang disusun secara sistematis dan jelas dalam satu kitab atau peraturan perundang-undangan. ${ }^{4}$

Hukum keluarga secara garis besar dapat dimaknai hukum mengatur tentang pertalian kekeluargaan. Pertalian kekeluargaan ini dapat terjadi karena pertalian darah, ataupun terjadi karena adanya sebuah perkawinan. Hubungan keluarga ini sangat penting sebab terkait dengan hubungan orang tua dan anak, hukum waris, perwalian, serta pengampuan. Hukum keluarga diartikan sebagai keseluruhan peraturan yang mengatur tentang hubungan kekeluargaan. Maksud kekeluargaan disini terdapat dua macam, yaitu pertama di tinjau dari hubungan darah dan kedua ditinjau dari hubungan perkawinan. Kekeluargaan ditinjau dari hubungan darah atau bisa disebut dengan kekeluargaan sedarah ialah pertalian keluarga yang terdapat antara beberapa orang yang mempunyai leluhur yang sama. Kekeluargaan karena perkawinan ialah pertalian keluarga yang terjadi karena sebab perkawinan antara seseorang dengan keluarga yang tidak sedarah dari istri (suaminya).

\section{Sumber Hukum Keluarga}

Sumber hukum keluarga Islam adalah alQuran dan al-Hadits. Kedua sumber tersebut kemudian digali yang hasilnya dapat berupa figh, fatwa dan bahkan peraturan perundangundangan (qânun). Tidak diragukan lagi bahwa banyak fiqh yang ditulis para ulama terkait dengan hukum keluarga Islam. Fiqh yang berkaitan dengan perkawinan dengan segala akibat hukumnya banyak terkondifikasi dalam fiqh munâkahat. Sedangkan fiqh yang terkait dengan pewarisan terkondifikasi dalam figh mawarits. Meskipun tidak berlaku secara yuridis formal, kedua produk hukum tersebut dapat dikategorikan sebagai hukum yang tertulis. Karena itu agar berlaku secara formal, produk hukum Islam (fiqh maupun fatwa) harus diadopsi menjadi peraturan perundangundangan.

Indonesia merupakan negara yang jumlah mayoritas penduduknya beragama Islam, namun konstitusi negaranya tidak menyatakan diri sebagai negara Islam melainkan sebagai negara yang mengakui otoritas agama dalam membangun karakter bangsa. Indonesia

\footnotetext{
${ }^{4}$ Muhammad Daud Ali, Hukum Islam dan Peradilan Agama. (Jakarta: P.T. Raja Grafindo, 1997), h. 90-91
}

mengakomodir hukum-hukum agama sebagai sumber legislasi nasional, selain hukum adat dan hukum barat. Kondisi demikian menyebabkan hukum Islam sebagai salah satu sistem hukum di dunia ini seperti "lenyap" di permukaan kecuali hukum keluarga. ${ }^{5}$

Dalam pembaharuan hukum Islam, Indonesia cendrung menempuh jalan kompromi antara syariah dan hukum sekuler. Hukum keluarga di Indonesia dalam upaya perumusannya selain mengacu pada kitab-kitab fikih klasik, fikih modern, himpunan fatwa, keputusan pengadilan (yurisprudensi), juga ditempuh wawancara kepada seluruh ulama Indonesia. Pengambilan terhadap hukum barat sekuler memang tidak secara langsung dapat dibuktikan, tetapi karena di Indonesia berjalan cukup lama hukum perdata (Burgelijk Wetbook) yang diterjemahkan menjadi kitab undang-undang hukum perdata, hukum acara perdata (reglemen Indonesia yang diperbarui) warisan Belanda, dan hukum-hukum lain, berdasarkan asas konkordansi, adanya pengaruh hukum Barat yang tidak bisa dinaifkan begitu saja. Seperti halnya bidang pencatatan dalam perkawinan, kewarisan, perwakafan, wasiat dan sebagainya. Upaya akomodasi ataupun rekonsiliasi hukum keluarga Islam agar sesuai dengan perkembangan zaman demi menciptakan ketertiban masyarakat menjadi salah satu bukti dari keunikan tersebut ${ }^{6}$.

Persoalan pencatatan dalam fikih klasik bukan menjadi sesuatu yang signifikan bila dibandingkan dengan tolok ukur kehidupan modern saat ini, akan tetapi bila ideal moral mengacu kepada semangat Alqur'an sangat jelas sekali bahwa Alqur'an secara langsung memerintahkan perlunya sistem administrasi yang rapi dalam urusan hutang piutang maupun transaksi perjanjian, sehingga masalah yang berhubungan dengan perbuatan hukum seseorang seperti perkawinan, kewarisan, perwakafan yang mempunyai akibat hukum lebih kompleks, pencatatan mempunyai peran

\footnotetext{
5 Mohammad Daud Ali, "Hukum Keluarga dalam Masyarakat Kontemporer ", Makalah, disajikan pada seminar nasional Pengadilan Agama sebagai Peradilan Keluarga dalam Masyarakat Modern, (Jakarta: Fakultas Hukum Universitas Indonesia dan Pusat Ikatan Hakim Peradilan Agama, 1993)

${ }^{6}$ Abdullah Saeed, Pemikiran Islam: Sebuah Pengantar. (Yogyakarta: Baitul Hikmah.2014), h. 103
} 
Eko Setiawan, Dinamika Pembaharuan Hukum Keluarga...| 141

yang lebih penting. Indonesia merupakan negara yang mayoritas muslim di dunia, sedangkan madzhab fikih yang paling dominan adalah madzhab syafi' $i$.

\section{Azas-Azas Hukum Keluarga}

Berdasarkan hasil analisis terhadap KUH Perdata dan Undang-Undang No. 1 Tahun 1974, dirumuskan beberapa azas dalam hukum keluarga, yaitu: (1) Azas monogami, azas ini mengandung makna bahwa seorang pria hanya boleh mempunyai seorang istri, dan seorang istri hanya boleh mempunyai seorang suami; (2) Azas konsensual, yakni azas yang mengandung makna bahwa perkawinan dapat dikatakan sah apabila terdapat persetujuan atau konsensus antara calon suami-istri yang akan melangsungkan perkawinan; (3) Azas persatuan bulat, yakni suatu azas dimana antara suami-istri terjadi persatuan harta benda yang dimilikinya (Pasal 119 KUH Perdata); (4) Azas proporsional,yaitu suatu azas dimana hak dan kedudukan istri adalah seimbang dengan hak dan kewajiban suami dalam kehidupan rumah tangga dan di dalam pergaulan masyarakat (Pasal 31 Undang-Undang No.1 Tahun 1974 tentang perkawinan); (5) Azas tak dapat dibagibagi, yaitu suatu azas yang menegaskan bahwa dalam tiap perwalian hanya terdapat seorang wali.

\section{Hak dan Kewajiban dalam Hukum Keluarga}

Sebagai suatu hubungan hukum, perkawinan menimbulkan hak dan kewajiban bagi suami istri. Yang dimaksud "hak" ialah sesuatu yang merupakan milik atau dapat dimiliki oleh suami atau istri yang timbul karena perkawinannya. Sedangkan "kewajiban" ialah sesuatu yang harus dilakukan atau diadakan oleh suami atau istri untuk memenuhi hak dan dari pihak yang lain. Hak dan kewajiban dalam hukum keluarga dapat dibedakan menjadi tiga macam, yaitu: (a) Hak dan kewajiban antara suami istri; (b) Hak dan kewajiban antara orang tua dengan anaknya; (c) Hak dan kewajiban antara anak dengan orang tuanya manakala orang tuanya telah mengalami proses penuaan. Hak dan kewajiban antara suami istri adalah hak dan kewajiban yang timbul karena adanya perkawinan antara mereka. Hak dan kewajiban tersebut diatur dalam Undang-Undang Perkawinan No. 1 Tahun 1974.

\section{Hukum Keluarga Islam di Indonesia}

Secara historis, hukum keluarga Islam mencuat kepermukaan bermula dari diakuinya peradilan agama (PA) secara resmi sebagai salah satu pelaksana "judicial power" dalam negara hukum melalui Pasal 10 UndangUndang No. 14 Tahun 1970. Lebih lanjut, kedudukan, kewenangan atau yurisdiksi dan organisatorisnya telah diatur dan dijabarkan dalam Undang-Undang No. 7 Tahun 1989, Undang-Undang No. 3 Tahun 2006, yang mempunyai kewenangan mengadili perkara tertentu: (1) perkawinan, (2) waris, (3) wasiat, (4) hibah, (5) wakaf, (6) infaq, (7) shadaqah, (8) zakat dan (9) ekonomi syari"ah, bagi penduduk yang beragama Islam.

Kenyataan bahwa keberadaan pengadilan agama belum disertai dengan perangkat atau sarana hukum positif yang menyeluruh, serta berlaku secara unifikasi sebagai rujukan. Meskipun hukum materiil yang menjadi yurisdiksi pegadilan agama sudah dikodifikasi dalam Undang-Undang No. 1 Tahun 1974 dan Peraturan Pemerintah No. 9 Tahun 1975, namun pada dasarnya hal-hal yang diatur didalamnya baru merupakan pokok-pokok. Akibatnya, para hakim yang seharusnya mengacu pada undang-undang, kemudian kembali merujuk kepada doktrin ilmu figh. Karena itu adanya perbedaan putusan hukum antar PA tentang persoalan yang sama adalah suatu hal yang dapat dimaklumi, sebagaimana ungkapan different judge different sentence. ${ }^{7}$ Dari realitas di atas, pemerintah kemudian berinisiatif melengkapi pengadilan agama dengan prasarana hukum yang unifikatif lewat jalan pintas berupa kompilasi hukum Islam (KHI).

Dalam teori sosiologi hukum, A. P. Craabree LLB menyatakan bahwa "law is clothes the living body of society". Hukum adalah pakaian masyarakat yang harus sesuai ukuran dan jahitannya dengan kebutuhan masyarakat. Intinya hukum itu mengikuti kebutuhan masyarakat dan mencerminkan

\footnotetext{
${ }^{7}$ Cik Hasan Bisri, Kompilasi Hukum Islam dan Peradilan Agama dalam Sistem Hukum Nasional, (Jakarta: Logos, 1999), h. 17
} 


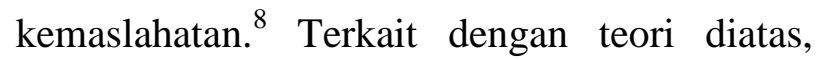
hukum keluarga Islam yang temuat dalam berbagai aturan hukum, bila ditelaah secara mendalam, memang masih mengandung banyak kelemahan sebagai konsekuensi logis dari dinamika kehidupan. Lebih-lebih bila dihadapkan dengan kebutuhan dan kompleksitas problematika masyarakat saat ini, harus dilakukan upaya mengaktualisasikannya atau pembaharuan. Seperti, menguatnya arus yang menghendaki adanya kesetaraan laki-laki dan perempuan atau menghapus hukum-hukum yang bias gender yang cenderung menjadikan perempuan dalam posisi subordinat, serta adanya perbenturan beberapa pasal dengan struktur dan pola budaya masyarakat.

Hal inilah yang kemudian menimbulkan minimnya renspon masyarakat untuk mentaati hukum keluarga yang ada yang selama ini. Jadi menurut saya, untuk itulah langkah pembaharuan hukum melalui proses kontekstualisasi menjadi keniscayaan. Kontekstualisasi hukum Islam, dalam arti bahwa hukum yang sudah ada dirumuskan kembali dengan perbaikan atau menambah poin-poin tertentu untuk disesuaikan dengan tuntutan perkembangan masyarakat. Di sini yang perlu diperhatikan adalah teks nash, konteks teks, konteks masyarakat Indonesia. Ketiga hal ini harus dijadikan pijakan proses kontekstualisasi, sehingga budaya-budaya lokal dan realitas kebutuhan masyarakat tidak tereleminasi.

Asumsi yang perlu dibangun adalah bahwa unifikasi hukum Islam tetap dibutuhkan demi kemaslahatan umum. Landasan ushul fiqh yang dipakai adalah "ma layudraku kulluhu layutraku kulluhu." Jangan kita membuang sesuatu, disebabkan tidak bisa dicapai keseluruhan yang benar-benar sempurna. Kesempurnaan yang mutlak, hanya ada pada sisi Allah.

\section{Kilas Balik Pembaharuan Hukum Keluarga}

Dalam catatan sejarah di Indonesia, isu pembaharuan hukum keluarga telah muncul sejak lama, sebelum kemerdekaan diraih. Pada momen Konggres Perempuan 1928, isu ini muncul karena banyaknya kasus yang menimpa

\footnotetext{
${ }^{8}$ Dadan Muttaqien, Peradilan Agama dan Kompilasi Hukum Islam dalam Tata Hukum Indonesia, (Yogyakarta: UII Press.1999), h. 80
}

kaum perempuan selama dalam kehidupan perkawinan. Seperti, terjadinya perkawinan di bawah umur, kawin paksa, poligami, talak yang sewenang-wenang dan mengabaikan hakhak perempuan dan sebagainya.

Pada tahun 1937, pemerintah kolonial Belanda pernah menyusun rancangan undangundang perkawinan modern yang disebut ordonansi pencatatan perkawinan. Langkah ini diambil atas desakan kuat dari organisasiorganisasi perempuan yang ada saat itu. Ordonansi pencatatan perkawinan ini berlaku bagi penduduk pribumi, Arab dan Asia bukan Tionghoa, yang ada di Indonesia. Hebatnya ordonansi ini menetapkan aturan monogami serta memberi hak cerai yang sama pada perempuan dan laki-laki. Meski begitu, ordonansi ini hanya diberlakukan bagi mereka yang memilih aturan pencatatan atas pernikahannya.

Pada tahun 1950, hukum perkawinan yang mengakomodir semua kepentingan lintas agama maupun ras yang ada di Indonesia, belum dimiliki negeri ini. Ordonansi perkawinan yang berazaskan monogami itu ditolak Pemerintah Republik Indonesia. Sebelumnya memang ada perundang-undangan pemerintah Republik Indonesia Tahun 1946, yang menetapkan pendaftaran perkawinan, menyarankan ketidaksetujuan pada perkawinan anak-anak dan perkawinan paksa, menyarankan agar pejabat perkawinan menasehati pasangan nikah tentang hak mereka, serta berusaha mencegah terjadinya talak dengan meneliti masalah dari kedua belah pihak yang berselisih (suami-istri). Tapi sayang, dalam praktik baik perkawinan anak-anak maupun paksa tetap banyak terjadi. Barangkali karena aturan tersebut hanya bersifat anjuran belaka. Akibatnya desakan adanya undang-undang perkawinan yang memberikan jaminan hak yang sama bagi semua warganegara, terus bergulir hingga terbentuknya komisi perkawinan pada tahun 1950.

Komisi perkawinan terdiri dari para ahli agama yang tentu saja mayoritas laki-laki, serta para tokoh perempuan dari berbagai kalangan, termasuk kalangan umat Katholik dan juga muslim. Dalam prosesnya, komisi ini berhasil merancang undang-undang perkawinan umum yang bisa digunakan semua warga negara Indonesia. Tetapi di dalam rancangannya, 
perkawinan didasarkan pada rasa suka sama kedua pasangan, dan poligami diizinkan dengan persyaratan yang ketat serta hanya dengan persetujuan agama si pasangan.

Ada hal menarik yang terjadi ketika masa berlangsungnya penggodokan rancangan undang-undang perkawinan oleh komisi perkawinan. Pemerintah saat itu membuat pengumuman melalui Keputusan No. 19 Tahun 1952, tentang aturan tunjangan pensiun bagi para 'janda' pegawai negeri. Dalam keputusan itu ditetapkan salah satunya adalah, dalam kasus poligami tunjangan pensiun diberikan dua kali jumlah yang diterima seorang 'janda' si pegawai agar dibagi rata dengan istri-istri lain yang tidak lebih dari empat orang. Sementara bagi pegawai negeri laki-laki pelaku poligami, menerima tambahan gaji. Ini berarti poligami diizinkan bahkan disokong negara dengan menggunakan uang rakyat untuk membayar biayanya. Ketetapan ini tentu saja menuai protes dan demonstrasi dari kalangan luas gerakan perempuan yang memperjuangkan hak-hak perempuan. Namun saat itu, tidak satupun organisasi perempuan muslim yang turut serta, karena ketidakleluasaan hubungan mereka dengan sejumlah organisasi agama yang dipimpin oleh laki-laki.

Demikian upaya pembaharuan hukum keluarga itu terus bergulir hingga tahun 1974. Oleh sejumlah tokoh dalam sebuah public hearing dengan Dewan Perwakilan Rakyat saat itu, diajukan tuntutan segera dibentuknya undang-undang yang mengatur tentang perkawinan, yang di dalamnya harus mengatur hal-hal antara lain: (1) Adanya kata sepakat dari calon suami dan istri untuk mencegah kawin paksa; (2) Ditetapkannya batas umur minimum untuk kawin, mengingat pentingnya kesejahteraan keluarga dalam suatu perkawinan; (3) Perkawinan berazaskan monogami dengan pengecualian yang sangat ketat; (4) Persamaan hak dalam mengajukan perceraian antara suami dan istri; (5) Pembagian harta benda bersama secara adil bila terjadi suatu perceraian.

Dengan tuntutan tersebut, akhirnya aturan yang dikehendaki itu ditetapkan melalui Undang-Undang No. 1 Tahun 1974 tentang perkawinan. Namun hukum adalah aturanaturan normatif yang mengatur pola perilaku manusia. Hukum juga tidak tumbuh dalam ruang yang vacum, tetapi tumbuh dari kesadaran masyarakat yang membutuhkan adanya suatu aturan bersama. Oleh karena itu, hukum seharusnya berkembang sehingga dapat mengakomodir nilai-nilai yang tumbuh di masyarakat, termasuk nilai adat, tradisi dan agama. Inilah yang dimaksud al-'adat muhkamat dalam teori Islam atau adat istiadat suatu masyarakat yang dapat dijadikan hukum.

Hukum seharusnya tidak menutup diri dari upaya pembaharuan, sesuai kebutuhan dan kemaslahatan bersama. Terlebih lagi idealnya sebuah hukum harus selalu menjunjung prinsip-prinsip dasar Islam dan nilai hak asasi manusia, seperti keadilan, kemaslahatan (maslahah), pluralisme (al-ta'addudiy), demokrasi (al-dimuqratiy), dan kesetaraan (almusâwah), khususnya kesetaraan di antara lelaki dan perempuan. Oleh karena itu, belakangan tuntutan akan adanya amandemen Undang-Undang No. 1 Tahun 1974 tentang perkawinan kembali marak. Tidak saja di Indonesia, di berbagai negara muslim lain pun dihadapkan pada tuntutan yang sama, mengingat hukum keluarga yang berlaku di negara mereka dirasa masih bias gender ${ }^{9}$ dan belum memenuhi hasrat keadilan bersama.

Tidak heran, upaya reformasi hukum keluarga ini selalu jadi isu kontroversi di negara-negara muslim modern. Sebagai konskuensinya, upaya pembaharuan hukum keluarga selalu menghadapi perlawanan kuat, khususnya dari kelompok "pemilik otoritas agama," Sebab mengubah hukum keluarga dianggap mengubah esensi agama. Upaya pembaharuan hukum keluarga bisa-bisa dimaknai sebagai "pembangkangan" terhadap syariat Islam. $^{10}$ Akibatnya, belum semua negara berpenduduk muslim melakukan pembaharuan terhadap hukum keluarganya. Demikian upaya pembaharuan hukum keluarga itu terus bergulir hingga 1974. Sejumlah tokoh dalam sebuah public hearing dengan DPR saat itu, diajukan tuntutan segera

\footnotetext{
${ }^{9}$ Bias Gender adalah kebijakan / program / kegiatan atau kondisi yang memihak atau merugikan salah satu jenis kelamin

${ }^{10}$ Syariat Islam berisi hukum dan aturan, disamping itu syariat Islam juga berisi penyelesaian masalah seluruh kehidupan ini. Maka oleh sebagian penganut Islam, syariat Islam merupakan panduan menyeluruh dan sempurna seluruh permasalahan hidup manusia dan kehidupan dunia ini.
} 
dibentuknya undang-undang yang mengatur tentang perkawinan.

\section{Dinamika Pembaharuan Hukum Keluarga Islam di Indonesia}

Bagi negara-negara muslim, pembaharuan hukum keluarga dimotori oleh Turki, pada tahun 1917, dengan hadirnya Ottoman Law of Family Rights atau Qanun Qarar al-Huquq al'A'ilah al-Uthmaniyah. Selanjutnya, pembaharuan Turki terhadap hukum keluarganya diikuti oleh sejumlah negara lain seperti, Libanon (1919), Yordania (1951), dan Syiria (1953). Turki sebetulnya masuk kategori negara Islam yang melakukan pembaharuan hukum keluarga secara radikal dan menggantikannya dengan hukum sipil Eropa. Sementara negara-negara muslim lain, hanya berusaha mengkodifikasi hukum keluarganya tanpa menghilangkan landasan pijak yang asasi, yaitu Alquran dan Hadits. ${ }^{11}$ Seperti yang dipraktikkan Mesir pada tahun 1920 dan tahun 1929, Tunisia, Pakistan, Yordania, Syiria, dan Irak.

Di Indonesia meski tidak tergolong negara Islam, melainkan mayoritas berpenduduk muslim, upaya pembaharuan hukum keluarga ini tidak terlepas dari munculnya pemikirpemikir reformis muslim, baik dari tokoh luar negeri maupun dalam negeri. Dari luar negeri bisa disebutkan antara lain Rifa'ah al-Tahtawi (1801-1874), Muhammad 'Abduh (18491905), Qasim Amin (1863-1908), juga Fazlur Rahman (1919-1988). Sedang tokoh dari reformis muslim nasional antara lain Mukti Ali, Harun Nasution, Nurcholis Madjid, dan Munawir Syadzali. Sosok Munawir Syadzali ini dikenal sangat kuat mendorong komunitas Islam untuk melakukan ijtihad ${ }^{12}$ secara jujur dan berani, terutama soal hukum waris. Gagasannya yang terkenal adalah tentang

11 Hadits adalah perkataan (sabda), perbuatan, ketetapan dan persetujuan dari Nabi Muhammad yang dijadikan landasan syariat Islam. Hadits dijadikan sumber hukum Islam selain al-Qur'an, dalam hal ini kedudukan hadits merupakan sumber hukum kedua setelah Al-Qur'an.

12 Ijtihad adalah sebuah usaha yang sungguhsungguh, yang sebenarnya bisa dilaksanakan oleh siapa saja yang sudah berusaha mencari ilmu untuk memutuskan suatu perkara yang tidak dibahas dalam AlQur'an maupun hadits dengan syarat menggunakan akal sehat dan pertimbangan matang. perlunya mengubah hukum waris, terutama mengenai pembagian yang lebih adil dan proporsional bagi (anak-anak) perempuan.

Memang bila dilihat dari tujuannya, pembaharuan hukum keluarga secara garis besar bertujuan 'meningkatkan status' perempuan dalam segala aspek kehidupan dan hukum keluarga termasuk juga waris. Meski tujuan ini tidak disebutkan secara eksplisit, materi hukum yang dirumuskan bahwa undang-undang seputar hukum keluarga yang dibuat umumnya merespon sejumlah tuntutan status dan kedudukan perempuan yang lebih adil dan setara. Undang-undang perkawinan khususnya yang dimiliki Mesir dan Indonesia jelas menggulirkan tujuan tersebut.

Tujuan lain yang dimiliki negara-negara Islam dalam memperbaharui hukum keluarga adalah unifikasi hukum. Usaha unifikasi hukum ini dilakukan karena masyarakatnya menganut bermacam-macam mazhab ${ }^{13}$ atau bahkan agama yang berbeda-beda. Di Tunisia misalnya, upaya unifikasi hukum perkawinan ditujukan untuk semua warga negara tanpa memandang perbedaan agama. Selain tujuantujuan tersebut, ada lagi tujuan lain dari upaya pembaharuan hukum keluarga yaitu untuk merespon tuntutan zaman. Dimana tuntutan zaman dan dinamika perkembangan masyarakat tersebut adalah akibat dari pengaruh global yang mempengaruhi hampir seluruh aspek kehidupan manusia.

Dalam reformasi hukum keluarga tersebut, umumnya upaya terfokus pada masalah status personal, yang masih diatur oleh hukum Islam yang telah mapan di beberapa negara muslim. Untuk mengurangi keberatan kaum konservatif, pembaharuan ini sering dilakukan secara tak langsung melalui jalur prosedural. Sebagai contoh, hukum baru yang menuntut persyaratan bahwa pernikahan harus dicatat agar sah secara hukum dan bahwa pasangan harus sudah mencapai usia minimum tertentu, adalah upaya untuk menghalangi pernikahan dini dan perkawinan paksa. Berkenaan dengan persoalan di atas, maka muncullah gagasan para mujtahid untuk mengadakan pembaharuan

13 Mazhab adalah istilah dari bahasa Arab, yang berarti jalan yang dilalui dan dilewati, sesuatu yang menjadi tujuan seseorang baik konkrit maupun abstrak. Sesuatu dikatakan mazhab bagi seseorang jika cara atau jalan tersebut menjadi ciri khasnya. 
dalam hukum, khususnya dalam hal muamalah yang menyangkut kepentingan umat, dalam hal ini diperlukan pula metode-metode yang masih relevan dalam mengistimbatkan hukum bagi para mujtahid. ${ }^{14}$

Untuk mengetahui metode-metode dalam pembaharuan hukum maka kita perlu memaparkan sedikit tentang konsep pembaharuan terlebih dahulu. Dalam literatur hukum Islam kontemporer, kata "pembaharuan" silih berganti digunakan dengan kata reformasi, modernisasi, reaktualisasi dan lain sebagainya. Diantara kata-kata tersebut yang paling banyak digunakan adalah kata reformasi. Reformasi berasal dari bahasa inggris "reformation" yang berarti membentuk atau menyusun kembali. Reformasi sama artinya dengan memperbaharui, asal kata "baru" dengan arti memperbaiki supaya menjadi baru atau mengganti dengan yang baru, atau proses perbuatan, cara memperbaharui, proses pengembangan adat istiadat dan cara hidup yang baru.

Dari konsep pembaharuan reformasi di atas dapat dimengerti bahwa yang dimaksud dengan pembaharuan hukum Islam adalah sebagai upaya atau perbuatan melalui proses tertentu dengan penuh kesungguhan yang dilakukan oleh mereka yang mempunyai kompetensi dan otoritas dalam pengembangan hukum islam (mujtahid) dengan cara-cara yang telah ditentukan berdasarkan kaidah-kaidah istinbâth hukum yang dibenarkan sehingga menjadikan hukum Islam lebih segar dan modern tidak ketinggalan zaman.

\section{Faktor-Faktor Penyebab Terjadinya Pembaruan Hukum Keluarga}

Menurut para pakar hukum Islam di Indonesia, pembaharuan hukum Islam yang terjadi saat ini disebabkan oleh beberapa faktor, diantaranya yaitu: (1) Untuk mengantisipasi kekosongan hukum karena norma-norma yang terdapat dalam kitab-kitab fiqih tidak mengaturnya, sedangkan kebutuhan masyarakat terhadap hukum terkait masalah yang baru terjadi sangat mendesak untuk

14 Secara bahasa mujtahid adalah orang yang melakukan ijtihad. Dan ijtihad secara bahasa yaitu mencurahkan segenap kemampuan dan usaha untuk melakukan sesuatu. diterapkan; (2) Pengaruh globalisasi dan IPTEK sehingga perlu ada aturan hukum yang mengaturnya, terutama masalah-masalah yang belum ada aturan hukumnya; (3) Pengaruh reformasi berbagai bidang yang memberikan peluang terhadap hukum Islam untuk bahan acuan dalam membuat hukum nasional; (4) Pengaruh pembaharuan pemikiran hukum Islam yang di laksanakan oleh para mujtahid baik tingkat internasional ataupun nasional.

Pembaharuan hukum Islam disebabkan karena adanya perubahan kondisi, situasi tempat dan waktu sebagai akibat dari faktorfaktor yang telah dikemukakan di atas. Perubahan ini adalah sejalan dengan teori qaul qadim dan qaul jadid yang dikemukakkan oleh Imam Syafi'i, bahwa hukum dapat juga berubah karena berubahnya dalil hukum yang diterapkan pada peristiwa tertentu dalam melaksanakan maqâsyid syari'ah. ${ }^{15}$

Dengan memperhatikan uraian diatas dapat diketahui bahwa pembaharuan hukum keluarga Islam telah terjadi dalam kurun waktu yang cukup lama, berproses dengan kondisi dan situasi serta sesuai dengan tuntutan zaman. Hal ini disebabkan karena norma-norma yang terkandung dalam kitab-kitab fiqh ${ }^{16}$ sudah tidak mampu lagi memberi solusi terhadap masalah baru yang terjadi. Sebagai contoh dalam bidang hukum keluarga seperti perkawianan yang ijab qabulnya dilakukan melalui via telepon, pemberian harta waris kepada anak angkat dengan cara wasiat wajibah dan lain sebagainya. Hal ini telah mendorong negara untuk mengaturnya dalam berbagai peraturan perundang-undangan.

\footnotetext{
15 Maqasyid syari'ah merupakan tujuan syari'ah yang lebih memperhatikan kepentingan umum.

${ }^{16}$ Fiqh adalah salah satu bidang ilmu dalam syariat Islam yang secara khusus membahas persoalan hukum yang mengatur berbagai aspek kehidupan manusia, baik kehidupan pribadi, bermasyarakat maupun kehidupan manusia dengan Tuhannya. Beberapa ulama fiqh seperti Imam Abu Hanifah mendefinisikan fiqh sebagai pengetahuan seorang muslim tentang kewajiban dan haknya sebagai hamba Allah. Figh membahas tentang cara bagaimana cara tentang beribadah, tentang prinsip Rukun Islam dan hubungan antar manusia sesuai dengan dalil-dalil yang terdapat dalam Al-Qur'an dan AlSunnah.
} 
146 | de Jure, Jurnal Syariah dan Hukum, Volume 6 Nomor 2, Desember 2014, hlm. 138-147

\section{Metode Pembaharuan Hukum Keluarga}

Adapun metode-metode pembaharuan hukum keluarga Islam ada dua yaitu diantaranya: Pertama, Metode Konvensional. Dalam penerapan metode konvensional, para ulama terlihat dalam berijtihad dengan merujuk pada ayat Alqur'an dan sunnah Nabi Muhammad. Para ahli menetapkan, ada beberapa ciri khas atau karakteristik metode penetapan hukum Islam yaitu: Menggunakan pendekatan parsial (global); (b) Kurang memberikan perhatian terhadap sejarah; (c) Terlalu menekankan pada kajian teks/harfiah; (d) Metodologi figh seolah-olah terpisah dengan metodologi tafsir; (e) Terlalu banyak dipengaruhi budaya-budaya dan tradisitradisi setempat, dan dalam beberapa kasus didalamnya meresap praktek-praktek bid'ah dan kufarat, $^{17}$ khususnya yang berkaitan dengan ibadah; (f) Masuknya unsur politik di dalamnya atau pengaruh kepentingan penguasa dalam menerapkan teori-teori fiqh.

Kedua, Metode kontemporer pada prinsipnya metode pembaruan yang digunakan dalam melakukan kodifikasi hukum Islam kontemporer ada lima yaitu: (a) Takhayyur yaitu memiliki pandangan salah satu ulama fiqh, termasuk ulama di luar madzhab, takhayyur secara substansial disebut tarjih; (b) Talfîq, yaitu mengkombinasikan sejumlah pendapat ulama (dua atau lebih) dalam menetapkan hukum satu masalah; (c) Takhshish al-qadla, yaitu hak negara menbatasi kewenangan peradilan baik dari segi orang, wilayah, yuridiksi dan hukum acara yang ditetapkan; (d) Siyasah syari'ah yaitu kebijakan penguasa menerapkan peraturan yang bermanfaat bagi rakyat dan tidak bertentangan dengan syari'ah; (e) Reinterpretasi nash yaitu (penafsiran ulang terhadap nash) melakukan penafsiran atau pemahaman ulang terhadap nash (Alqur'an dan sunnah Nabi Muhammad SAW).

Adapun dasar pertimbangan yang digunakan dalam menggunakan metode-metode tersebut diatas ada minimal 2 yakni: mashlahah mursalah dan konsep yang lebih sejalan dengan tuntutan dan perubahan zaman.

\footnotetext{
${ }^{17}$ Pengertian kufarat dalam Islam ialah semua cerita sama ada rekaan atau khayalan, ajaran-ajaran., pantanglarang, adat istiadat, ramalan-ramalan.
}

Sementara dasar dalam melakukan reinterpretasi nash muncul dalam empat bentuk yaitu: (a) Ada negara yang menggunakan pendekatan tematik dan integratif, meskipun penggunaannya belum konsisten dan belum sistematis terhadap semua masalah; (b) Ada negara yang menggunakan dasar analogi (qiyas), maksudnya mencari kesamaan hukum antara kasus yang sudah ada ketetapan hukumnya dalam nash dengan kasus baru yang ketetapannya hukum belum ada; (c) Ada negara yang mendasarkan pada mashlahah, maksudnya penetapan hukum berdasarkan untuk kepentingan orang banyak, dan ketetapan hukum tersebut tidak bertentangan dengan syari'ah; (d) Ada negara yang mendasarkan pada pemahaman penafsiran secara kontekstual.

Pembaharuan hukum Islam adalah upaya untuk melakukan penyelarasan pemahaman dan aplikasi ajaran Islam dibidang hukum dengan kemajuan modern dengan tetap berdasarkan pada semangat ajaran Islam. Adapun tujuan pembaharuan hukum keluarga Islam secara umum dapat pula di kelompokan sebagai tersebut, yaitu: (1) Unifikasi hukum perkawinan; (2) Peningkatan status wanita; (3) Respon terhadap perkembangan dan tuntutan zaman; (4) Memberikan kepastian hukum bagi masalah-masalah perkawinan; (5) Menjadi pegangan hakim.

\section{Kesimpulan}

Pembaharuan hukum keluarga Islam dapat dilakukan sesuai kebutuhan dalam batasbatas yang ditetapkan syariat. Pembahasuan hukum keluarga yang keluar dari ketentuan syariah merupakan suatu kesalahan, meskipun dengan dalil untuk kemaslahatan, keadilan, kesetaraan maupun istilah-istilah lainnya. Metode-metode pembaharuan hukum keluarga Islam ada dua yaitu metode konvensional dan metode kontemporer. Tujuan pembaharuan hukum keluarga Islam yang dilakukan di Indonesia merupakan upaya untuk menjawab tantangan modernitas dalam bidang hukum keluarga, karena pemahaman konvensional yang mapan tentang berbagai ayat Al-Quran, Hadits dan kitab-kitab fiqh dianggap tidak mampu menjawab tantangan problem hukum keluarga yang muncul pada era moderen. 


\section{DAFTAR PUSTAKA}

Ali, Muhammad Daud. Hukum Islam dan Peradilan Agama. Jakarta: P.T. Raja Grafindo. 1997.

Ali, Mohammad Daud, "Hukum Keluarga dalam Masyarakat Kontemporer, 1993. Makalah disajikan dalam Seminar Nasional Pengadilan Agama sebagai Peradilan Keluarga dalam Masyarakat Modern, Fakultas Hukum Universitas Indonesia dan Pusat Ikatan Hakim Peradilan Agama (Jakarta, 1993)

Bisri, Cik Hasan. Kompilasi Hukum Islam dan Peradilan Agama dalam Sistem Hukum Nasional. Jakarta: Logos. 1999.

Donohue, John. Islam dan Pembaharuan Ensiklopedi Masalah-Masalah. Jakarta: Rajawali Press. 1995.
Mudzhar, M. Dampak Gender Terhadap Perkembangan Hukum Islam. Jurnal Studi Islam. Volume ke-1 Nomor 1: 1999.

Muttaqien, Dadan. Peradilan Agama dan Kompilasi Hukum Islam dalam Tata Hukum Indonesia.Yogyakarta : UII Press. 1999.

Saeed, Abdullah. Pemikiran Islam: Sebuah Pengantar. Yogyakarta: Baitul Hikmah. 2014. 